\title{
Staking a Claim: Eight Mt Isa novels
}

Cheryl Taylor

cheryl.taylor@griffith.edu.au

Mt Isa's story is an Australian foundation epic. Only heroic struggle could have dug the mine and built the city a thousand kilometres from the nearest deepwater port, in a scorched red landscape sparsely dotted with spinifex and eucalypts. In Mines in the spinifex (1970), Geoffrey Blainey celebrates the fortitude of the prospectors and entrepreneurs who overcame these obstacles to found what he calls 'the greatest Australian mine of the [twentieth] century' (1970: 64).

First published in 1960, Blainey's book domesticates the tradition of nationbuilding epics like The Aeneid by introducing down-to-earth elements from the Australian version of the universal mining romance. ${ }^{1}$ Blainey recounts how the meditative station-hand John Campbell Miles discovered lead on the site in February 1923. He describes Miles' friendship with 'the lean, comical red-bearded bushman' Bill Simpson (1970: 70); the gougers' opening-up of the field; William H. Corbould's establishment of Mt Isa Mines and the company's absorption of its rivals; and the steps by which directors and managers overcame the tyranny of distance, industrial strife and price fluctuations to the benefit of both investors and workers - a triumphant tale.

Adherence to the mythology of diggers and bush mateship is one aspect of the conservatism of Blainey's book, which was commissioned by Mt Isa Mines (1970: 245) and tacitly supports company hierarchies based on responsibilities, skills, and wealth. Blainey describes the building of the town with few references to women or immigrant workers. ${ }^{2}$ Aboriginal people appear as ambushers of lonely fossickers, and as labourers in Ernest Henry's copper mines in the 1880s. Kalkadoon resistance, quelled in 1884 at Battle Mountain, and the role of Indigenous people in Mt Isa's twentieth-century evolution are notable absences.

For the purposes of this article, these features equip Mines in the spinifex as a thesis against which I interpret a group of novels that, politically, are mostly antithetical to it. In terms of numbers of texts, the humanising impulse behind the novels has proven to be more productive over time than the corporate power that funded Blainey's research. Even together, however, the novels do not fill every ideological gap in Blainey's account, nor do they challenge all of his book's assumptions. My aim, therefore, is to use the whole group of texts as a basis for mapping the discursively created 'mind' of the mining city of Mt Isa, as this appeared to residents and other Australians during the twentieth century. My article is supplementary to Ian Syson's 1995 study of Mt Isa literature, which first discerned this field of research.

The eight novels reflect the transitory nature of Mt Isa's population in being the work of visitors rather than long-term residents. The exception is Knock ten: a novel of mining life (1976), written by Kay Brown, who grew up in a railway 
siding town in north-west Queensland and lived in Mt Isa after World War II. However, fiction overrides the factual base in both Knock ten and John Jost's Kangaroo court (1979). Jost worked as a correspondent for the National Times and Melbourne Age in the 1970s, and became a noted Melbourne broadcaster. Vance Palmer's two visits to Mt Isa in 1924 and 1957 (see Palmer 1957b) inspired his Golconda trilogy, comprising Golconda (1972, first published 1948), Seedtime (1957a) and The big fellow (1973, first published 1959). The trilogy loosely follows E. G. Theodore's career from union secretary at Irvinebank to Queensland Labor premier. Betty Collins' novel The copper crucible (1996) was first published in 1966 with a supplementary account of the 1964-65 industrial strife. It was reprinted in 1996 in the form it took when first completed in 1963, based on the author's 1957 residence in Mt Isa. The channels (2001), an autobiographical prose poem published by Dorothy Hewett's husband Merv Lilley, narrates the 1948 strike over the lead bonus from the perspective of a labourer and Communist. Keith De Lacy's Blood stains the wattle (2002) likewise draws on first-hand experience and observation, focused on the 1964-65 lock-out. Using Peter Mooney as a thinly disguised alter ego, De Lacy — who was Queensland Labor Treasurer from 1989 to 1996 and who, as a leading public figure, is or has been chairman or director of a long list of sugar, mining, energy and casino companies - romanticises the epoch-making struggle from the perspective of a novice miner.

The following discussion draws on these novels according to their main concerns, in order to map the twentieth-century 'mind' of Mt Isa under the sub-headings of Country, Men and Women.

\section{Mt Isa Country}

Paintings by Kalkadoon artists like Sid Domic ${ }^{3}$ and settler artists like Janet Fountain ${ }^{4}$ call forth a redemptive beauty from the hot, dry Mt Isa country. By contrast, Vance Palmer's Golconda trilogy converts the country into literary art of complex meaning, but ultimately of negative judgement. For Palmer's contemporaries, the word 'Golconda' conjured up the legendary diamond mines of India. ${ }^{5}$ The trilogy's name represents both the drive for wealth that built the mine and settlement, and the epic proportions of the task. Lost opportunities and the petering out of dreams shattered by greed and ambition are its overriding themes. These themes put the seal on what Julian Croft (1988) perceives as a major preoccupation of Australian writing in the 1930s and 1940s, namely 'the collapse of idealism' and 'the tragedy of Australian life and its usually thwarted struggle to break free from a deterministic and inescapable historical process' (1988: 422). The title novel describes how, even in reviving after early rains, 'the rigid framework of the country ... had no interest in idyllic dreams ... any life that was built in it must be based on solid rock' (Palmer 1972: 95).

The particular dream for the Australian continent that the unfolding of Golconda symbolically denies is that of a free and equal community. The old gouger Christy Baughan, who joined William Lane's utopian experiment in Paraguay and now lives alone on top of the mineral mountain on his ironically named claim of Cosme, ${ }^{6}$ is this dream's prophet and preacher:

We will write the name of humanity, we told ourselves, on the rocks of the Andes. But why not here, on the face of this old continent that has lain so long alone? 
Sometimes we hear it whisper to us in a voice only we who are part of its dust can understand. Listen in the silence and you will hear it; it sends out a message to us to humanise it, steep it in our affections, rear children on its lean soil who will cherish it, not exploit it; make it blossom, not with iron derricks tearing out its riches for others but with the fruits of true comradeship. (1972: 105-6)

The young sculptress who befriends Christy, Neda Varnek, is instinctively in tune with his vision, but the ambition of Neda's lover and the trilogy's protagonist, Macy Donovan, involves him in the struggle between capital and labour that is destined to dominate Golconda's future. Christy's vision for Golconda ultimately dies with him. From the perspective of Fred Mahony, who functions in Golconda as a mentor and foil to Donovan, the ensuing industrial ugliness and its decay symbolise the inescapable fate of Australia as a whole:

No happy communal living, such as Christy imagined, would ever grace this ragged flat where the earth crumbled in poisonous dust and the very grass had the menace of spears. Great machines would tear the heart out of the mountain, evil fumes cloud the air above its head, there would be savage fights about wages and profits. And it would be as ugly in the insolence of its power as in the ghostliness of its inevitable decline. (1972: 196)

Furthermore, Golconda's complex suggestiveness objectifies Donovan's own progress. Early on, it features as 'the dark mountain' (1972: 18), its ore-loads as mysterious as his future; later, it looms over his strivings as union representative, but when he finally flies out as an elected MP but failed lover, his half-realised ambitions dwarf the mountain:

Staring down on it, Donovan was struck sharply by its insignificance, and that of the crawling life about its base, against the vast background of sky and desert. A few tiny figures moved along the hot threads of track; they greeted one another like ants and passed on; trucks no bigger than beetles stirred up a faint dust. (1972: 286)

Three years later, when Donovan revisits Golconda in Seedtime (1957a), another flight image deepens the novel's insight into the fantasy lives of ambitious men: over the 'toothpick masts and spidery derricks, the human ants crawling about their work, the leagues of tumbled plain, reaching north to the Gulf, west to the heart of the continent, he dipped and wheeled ... buoyant as an eagle' (1957a: 143). However, when at the end of The big fellow (1973) Donovan returns on his last visit, still Premier but with his political future uncertain, the gutting of Golconda by the now giant-sized machinery realises Mahony's prediction of doom for both the mine and the nation. Moreover, Golconda now testifies to an inner emptiness that Donovan can never fill, stemming from his abortive relationship with Neda:

Even the mountain itself had lost its effect of primeval power. Machines had torn off its crest, and from a flattened base rose a tracery of derricks that looked like the work of mammoth spiders. What remained of the mountain was less impressive than the slag that had been torn from its vitals and now towered in a giant pyramid beside it, blue-black in the afternoon light. (1973: 291)

Golconda also stands in the trilogy for the irresistible creative drive that tragically attenuates love and relationships in Neda's life. As a girl, she gains an artist's 
understanding of the mountain, scouring it for fragments of ribbonstone to carve into jewellery, and by night she connects with the generative power at its heart (1972: 73). As a mature woman in The big fellow, however, she questions the benevolence of the mountain's creative forces:

What was Golconda? A great mass of stone thrusting its head out of the earth. Strange shapes of rock, some of them frightening, that used to haunt me before I went to sleep. I remember feeling there were forces beneath that iron earth struggling to break through, and that I wanted to help them. Not that I liked them: often the thought of them filled me with awe; but because I felt that they'd a right to get out into the daylight. Even though they might prove to be monstrous or evil. (1973: 118)

The five novels written later than the Golconda trilogy are less imaginatively complex in their representations of Mt Isa country. In a chapter that invites comparison with Gavin Casey's 'Short-shift Saturday', The copper crucible (Collins 1996) describes gruelling conditions endured by underground miners, and denounces exploitation by the company at a time of 'soaring profits' (1996: 51). In a way that complements Casey's Kalgoorlie mining story, however, Collins's main focus is on miners' wives, who swelter in the frying temperatures of Townside's cramped huts and garages. Her protagonist, Julie Spiros, flies into the town - renamed Mount Irene - across 'the copper coloured desert', where 'there seemed no life, only mile upon stretching mile of red-brown rock, corrugated into waves and troughs like some long petrified sea' (1996: 1). Needing later to 'look out at the world that lay outside the dusty, ugly valley' (1996: 56), Julie and her friend Bronwyn discard their tops for coolness and walk to the top of a hill, only to find the town 'grown small in the distance' but still 'dominated by the smelter chimney and its ever-belching smoke' (1996: 56). The landscape persists in denying their yearned-for freedom: 'Far away, another little ring of hills like their own closed them in again' (1996: 56-7). Like all the novelists in this group, Collins conceptualises Mt Isa country - which later ecologists have found to be brimming with life - purely in human terms.

Merv Lilley's The channels (2001) confines its protest against corporate power to miners and to the men who work in the lead smelters:

Injustice has been put in place where all that had and has been asked for is a sensible slice of the cake they pour into moulds every day - with a few currants thrown in for work faithfully performed, from lives minute by minute poured into the crucibles, blown away in desert gales, in bed in a monastery of lead, locked away from civilised amenities in the world's cities. (2001: 48-9)

Like The copper crucible, The channels therefore convicts the Mt Isa landscape as an accessory in the systemic suffering imposed on the working class.

The dystopic vistas of The copper crucible intensify to sensationalism in Kangaroo court (1979), set in and near Corbett Waters, a dying gold and copper town on the road to Mt Veracity, which like Mt Isa is a district hub. The violent story of Paul Kovac, a sexual predator punished with castration by a kangaroo court, is closely tied to its remote setting. Dan Murphy, the father of the teenage girl abused by Kovac, has always lived in Corbett Waters, and traces his ancestry to the town's 
founders. Simson, from country Victoria, provides an outsider's sane perspective on brutal scenes set far from knowledge of any civilised values.

Blood stains the wattle romanticises the interactions of its working-class characters in the pub, the mine and at home, and gives non-specific descriptions of the town and surrounding country. As a romance of labour, it contrasts both with Blainey's pioneering and corporate romance, and also with Collins' and Lilley's view of Mt Isa country as an accomplice in proletarian suffering.

In Knock ten (1976), the narrator, Lee Cleary, is the only daughter in a large Irish-Australian Catholic family. She and most of the other characters grow up, marry and die at The Mount, which becomes a collecting point for their stories. Brown's fictional community is by no means a utopia, but it invites judgements about the district that contradict those suggested by The copper crucible, The channels and Kangaroo court. Families at The Mount earn the reader's admiration by their courage during mining accidents - the signal for which is 'knock ten', or ten eerie clangs on the miners' lift cage. In contrast to Mines in the spinifex, Knock ten explores the paradox whereby the mining industry, which attracts the people and maintains the town, is simultaneously the underground enemy of its own creation.

In opposition to Blainey's promotional history, therefore, disappointment, danger and discomfort predominate in the humanised versions of Mt Isa contained in the eight novels. Written by authors who knew the mine and the town in their youth, Knock ten and Blood stains the wattle affirm human resilience in learning from and overcoming the disadvantages of place. By contrast, Palmer develops a complex symbolism around Golconda that illuminates the tragic failure of equal community throughout the new continent of Australia, where people's lives are doomed to stay tragically unfulfilled. Collins, Lilley and Jost go a step further, by fictionalising Mt Isa country as a place of isolation, exploitation and violence that ultimately is destructive to both the men and the women who live there.

\section{Mt Isa Men}

Male-authored, and written before second-wave 1960s feminism had deepened awareness of gender issues in Australia, the Golconda novels assume men's inherent superiority and social pre-eminence. On this foundation, Palmer constructs an ideal of Anglo-Irish Australian manhood that features realism, altruism, clear-sightedness and composure during crises. At Golconda, this ideal manifests both in Fred Mahony, northern representative of the AWU, and in Keighley, manager of Golconda Mining Company - the trilogy's equivalent of Mt Isa Mines.

After Mahony's misappropriation of union funds to pay gambling debts leads to the loss of his job, he returns to Golconda as a labourer and, in a redemptive upward spiral, builds a marriage with the settlement teacher, Dora Venn. As observed by Donovan in Seedtime (1957a), Mahony balances physical toil with a happy family life, while staying cheerfully disillusioned and clear-sighted: 'his tongue had a sardonic buoyancy when he assured Donovan that before another generation had passed the whole world would be made over and made better' (1957a: 147-8). Finally, in The big fellow (1973), Donovan recalls drinking with Mahony twenty 
years earlier in a Golconda pub: 'A man you'd never forget ... Dinkum all through. Never asking what he could get out of life, but what he could give.' (1973: 297)

The trilogy's analogous approval of Keighley also invites comparisons with the positive portrayal of Mt Isa managers in Mines in the spinifex, except that Palmer deepens Keighley's character with self-doubt, stemming from his limited early success in managing smaller companies. The unfolding of Golconda affirms Keighley's cool-headedness in negotiating both with the gougers, and with the Anglo-American Mining Company in its drive to take over the mining field. The record of Keighley's escalating triumphs offers vicarious fulfilment to male readers.

The narrative of Donovan's rise to power at Golconda consummates Palmer's composite affirmation of male competency: 'The way he had won authority over that small camp, controlling its life, earning the respect of its men and women, had become a legend that shaped all his conceptions of himself.' (1973: 34). Throughout the trilogy, Donovan's leadership consists of rescuing or protecting others, thereby displaying a capaciousness of being that justifies his title of 'the big fellow'. The epithet also implies his self-confidence in overcoming obstacles and his refusal to succumb to 'the human warmth of the mass' - 'he had never had a mate' (i.e. male friend) (1973: 295). Ultimately, however, Donovan's failures in relationships with women and the younger generation, including his own children, and his inability to impinge on Neda's creative core, hollow out his external triumphs from within.

That Palmer is in fact almost as interested in men's failures as their successes is indicated by the trilogy's exploration of challenges to Australian men's self-image from the 1920s into the 1950s. In Mines in the spinifex (1970), diggers are static types reasserting a nationalist myth, but Golconda steers this model into the twentieth century by recording the gougers' gradual displacement by workers, unionists and managers. In letting slip the opportunity to rebuild Paraguayan Cosme on the slopes of Golconda, the gougers reveal individualism as a weakness at the heart of the 'digger' stereotype. The narrative also suggests that the romantic mateship ideal is vulnerable to the exigencies of industrial life, when the heroic friendship between Golconda's discoverers, Charlie Gessler and his mate McVeigh, forces their early retirement from the field.

Throughout the trilogy, white men of Anglo-Irish background are accepted as the male norm, a view that reflects pre-World War II ethnicity in Mt Isa and the Australian sub-tropics. The rare allusions associating Aborigines at Golconda with mysteries that elude the rational world of industry and politics accordingly pose no challenge to white male hegemony. The standard image - found also in Mines in the spinifex - of 'myalls ... lurking just outside the circle of firelight' (Palmer 1972: 48) as a danger faced by lonely gougers nevertheless takes on a symbolic force. Greek and Italian men - 'dagos' in the parlance of the era - occupy a similar discursive position to Aborigines as an alien mystery. However, unlike Aborigines - whose culture the trilogy relegates to a primordial past - non-British European men gradually emerge as a present threat. They haunt the Golconda trilogy as a feminised shadow, menacing the robust sunshine of Anglo-Irish manhood.

For example, the 'little Greek', Joe Comino, is first defeated in a fist-fight for cheating, and soon afterwards knocked unconscious in a brothel. From this positioning with the marginal and subliminal, Joe raises himself by cunning to become financier of Golconda's public buildings. When Mahony, debilitated from his gassing at the Somme, is struggling to work as a navvy, Joe offers him an 
appointment as a manager, thereby playing bad angel to Dora's good angel. Mahony's refusal of Joe's overtures classifies him as a man who has overcome his weaknesses. Palmer's descriptions of Joe adopt the judgements of European immigrants as dark, subversive influences that were common among Australian workers in the 1940s and 1950s:

a small olive-faced man edged toward him with a grin, white teeth showing their gold, beady eyes gleaming behind a cloud of cigar-smoke ... Mahony studied the sharp, swarthy face that, with its innumerable faint lines round the eyes and mouth, seemed old as a totem-carving, yet filled with mysterious energy. The energy of some creature that kept close to the ground. (1972: 197-8)

The Italian bird-catcher Farelli wields a similar insidious power over Neda:

Those hundreds of painted finches trapped as they picked at the strewn seed beside the water, vibrating against the cords in a tumult and flurry of living colour, beating their little hearts out in an effort to get away. And Farelli's eyes as he thrust his hands in amongst them, pawing them, calling excitedly to her for help to get them into the cages ... But it was the hint of a cat in his eyes and out-thrust paws that had roused her. She had been shaken by a vision of what their life together would mean. (1972: 185-6)

This passage epitomises the sexual threat that post-war Anglo-Irish Australian men may have perceived in the immigrants. Neda flees back to Golconda but, like the finches, never truly escapes Farelli. His chameleon quality reappears in Seedtime, which opens when Donovan is stabbed in a Brisbane brothel by an Italian he thinks is Farelli, but later identifies as a north Queensland cane farmer.

Farelli's enigmatic, perilous quality deepens in his and Neda's son, Leo. Neda captures this alien mystique in a bust that she sculpts of Leo as

a young faun, prick-eared, knowing, with a tuft of hair rising above the forehead and a smile that seemed to reside in one corner of the mouth. There was a beauty about the modelling of the narrow head and the small, fastidious nose that even Donovan could feel; yet it was a beauty that had in it something disturbing. (Palmer 1973: 89)

Leo later shatters the bust in a rejection of this attempt to contain his spirit. Its elusive essence nevertheless suggests the unspoken challenge that European migrants and refugees who entered Australia after World War II posed to constrictive notions of manhood already shaken by the wartime influx of American servicemen. Subsequently in The big fellow (1973), Donovan uses political influence at Neda's request to release Leo from a reformatory, only to find that Leo's presence drives the wedge between Neda and himself deeper, until Leo's violent death while committing a robbery permanently separates them.

The final chapter of the trilogy (1973: Chapter XXXIII) confronts political repercussions of immigration, when Donovan, as the leading representative of AngloIrish Australian masculinity, confronts the New Australians now commingling at Golconda-Mount Isa: 'Italian taxi-drivers darted about on the look-out for homegoing workers who might have the price of a fare. Listening to the noisy arguments in half a dozen languages filtering up from the bar below, Donovan felt an outsider.' (1973: 291) He imagines the speech, damning the 'reds' as agents of a foreign 
power, which he might make to win back voters from the 'young fellow' (1973: 293) who has defeated him in the pre-election ballot:

'Morovitz! What a name to get your tongue around! Donovan's blood cooled and doubts began to trickle through his mind. Where was he letting this stream of feeling carry him? Could he, after all these years, surrender to the Irish in him and make himself the mouthpiece of a faction? (1973: 294)

In the Golconda trilogy, Mt Isa therefore functions as the fictional setting for an exhaustive exploration of Australian masculinities in transition during the middle decades of the twentieth century. The narrative problematises the bush digger and mateship mythologies by placing them inside the mining industrial complex, and deplores the impact of Aboriginality and introduced European cultures on AngloIrish ethnic assumptions. Through Macy Donovan, the trilogy defines the strengths and weaknesses accruing to leadership. In Keighley and Mahony, it models realism and clarity as the leading qualities of an Australian masculine ideal that bridges the gap between management and labour.

Most of the later Mt Isa novels maintain the trilogy's focus on Anglo-Irish Australian men as the ethnic norm, or extend the trilogy's negative image of immigrant miners. The exceptions are the two female-authored novels, The copper crucible (Collins 1996) and Knock ten (Brown 1976). Lilley's account of the 1948 Mt Isa strike meetings and De Lacy's tales linked to the 1964 lock-out are blind to the significant part played by immigrant miners and unionists. In Blood stains the wattle (De Lacy 2002), Pat Mackie, the charismatic American strike leader, remains an ambiguous figure, but Anglo- and Irish-Australian workers and their families are idealised. Hyperbole and romance, colourful events and characters abound, as De Lacy's book reactivates in the twenty-first century a mythology of working-class solidarity that emerged a century earlier, when the bush mateship mythology first repositioned itself in the cities.

The copper crucible is a social realist novel, the Russian translation of which sold over 160,000 copies in the late 1960s. The narrative upholds the dignity of working men in its portrayals of Finnish, Czech, Russian, Dutch, Greek and AngloIrish Australian unionists during the skirmishes with Mt Isa Mines that preceded the 1964 lockout. Julie's husband, Nick Spiros, who is black-listed by management for his union activities, is a hero in the world of work. From Julie's perspective, however, the novel provides a view of Nick that fills out the symbolic caricaturing of immigrant men in the Golconda trilogy with domestic details. Collins explains Nick's selfish domination of his wife and the exploitation of her work as secretary to a drunken solicitor, and Julie's revolt, as being culturally based. She describes the Greek wedding ceremony, in which the bride kisses the groom's hand and promises obedience, as being incompatible with Australian women's sense of equality (Collins 1996: 124). Despite the narrator's effort to be fair to all her characters' upbringing and prior conditioning, Nick's selfishness, childish vanity and likely unfaithfulness dominate the depiction of men in the private sphere in The copper crucible. Nick and Julie's riven marriage nevertheless contrasts with the romance between a Finn, Gerry Johansen, and nursing sister Ruth Carver. Gerry's courage in confronting mine management and his genuine love for Ruth help to counterbalance the novel's central critique of Nick. 
In Kovac - whose name suggests an Eastern European origin - Kangaroo court amplifies the racist depictions of immigrant men in the Golconda trilogy. Jost's novel compresses Palmer's thoughtful exploration of male vulnerabilities into a primal dread of castration. Early scenes mix suspense with pornography and violence, as they dwell salaciously on Kovac's meetings with Dan Murphy's wife Kath, her fifteen-year-old daughter Elizabeth and Elizabeth's schoolmate Tricia Lardner. Kovac emerges as a coward whose identity is based on sexual prowess, and who - like Palmer's Joe Comino - triumphs through cunning. When Murphy catches Kovac with the undressed schoolgirls, he and his mates - among them Tricia's father - take Kovac into the bush with the object of putting him on trial. Only the outsider, Simson, can be found to speak in Kovac's defence (195). Tension mounts through ugly scenes, as Murphy's mates baulk at witnessing Kovac's execution, decreed by the kangaroo court. Lardner and Simson at last reverse the power balance by seizing Murphy's rifle, but during the momentary relief that follows Murphy castrates Kovac with a concealed knife. The story ends with Murphy tragically insane in a police cell.

Kay Brown's innate humanity and leftist affiliations, including her friendship with Jean Devanny, account for the inclusiveness evident in Knock ten's (1976) depiction of male characters. The narrative idealises Lee Cleary's father, Big Dan, and his three 'strapping' elder sons, who are high-paid miners at The Mount, but pays more attention to males who transcend or challenge the Irish-Australian working-class norm. Among these are virtuoso pianist Ossie O'Brien, and Thad Barrigg, the son of a violent drunk, who survives at The Mount by charm and trickery. When Thad loses his legs in the novel's climactic mine disaster and later marries his childhood sweetheart, the narrator admires his joyful effrontery. Knock ten embraces a wider ethnicity when Mollie O'Brien — who, like Lee, is a Catholic daughter - marries a European Jew, Solomon Goldenberg. In what is clearly a novelistic reaction against the Holocaust, Solomon is made the model for an alternative, highly esteemed version of masculinity. Distinguished by a youthful appearance, fragility and beauty, in Lee Cleary's experience he was 'not like men were at all' (1976: 121).

As might be expected, given the traditions of the mining industry, the Mt Isa novels are mostly male oriented. Only the Golconda trilogy explores complexity in the inner lives of male characters, and charts changes occurring in Australian male mythologies over time - post World War I into the 1950s. Most of the novels notably The channels (2001) and Blood stains the wattle (2002) - take AngloIrish Australian miners as the norm while excluding reference to immigrant workers and their families. In the trilogy, immigrant men emerge as a half-realised threat to a pre-existing Anglo-Irish masculine hegemony. In Kangaroo court (1979), the immigrant Kovac is a monster of lust who meets a dreadful fate. However, like his torturers - including the Irish Australian Murphy - Kovac is above all a victim of the violence generated by life in isolated mining districts like Mt Isa. Perhaps because they are women, and therefore outside observers of male behaviour, Collins and Brown are comparatively balanced and wide-ranging in their fictionalising of Mt Isa men. The copper crucible critiques Nick Spiros as a domineering husband, but counters this by positive assessments of other immigrant men in both the private and public spheres. Knock ten consciously expands the male Anglo-Irish paradigm with admiration for Jewish, sensitive, artistic and disabled men. 


\section{Mt Isa Women}

Perspective - again seemingly decided by the author's gender - is the leading determinant of female characterisation in the eight novels under discussion. All the male-authored works assume women's inferiority in ability, status or complexity, and all try to penetrate the so-called feminine mystique. However, Collins's and Brown's female perspectives challenge both the male hegemony over Mineside and Townside, and the gendered assumptions of the other novels.

Depictions of the prostitutes who have always been a part of life in Mt Isa encapsulate this author-based division. In Golconda, the women at Mother Gregson's arouse Donovan's trepidation and disgust:

One of them was the old woman's daughter: she was a prettyish, half-witted girl of twenty or so, with a mouth that did not quite close and a fading chin. Her straw-coloured hair was straggling over her forehead and she clutched at the folds of a soiled kimono that was wrapped round her body. The other girl was partly Chinese, with small features and eyes like slugs. (1972: 65)

The same scene later challenges his reaction: “"They're women battling for a living," said May calmly. "I haven't found them bad neighbours." (1972: 67) Kangaroo court once again simplifies Palmer's more nuanced approach. In the last sexual scene of many, Kovac bribes an Aboriginal woman, Daisy, with a bottle of rum. The narrative paints Daisy as a denizen of the fringe camp, pitiable and physically disgusting, but ironically empowers her against Kovac. About to flee Corbett Waters, he warns: 'I'll cut your tits off if you tell anyone you saw me.' He then hears the voices of Murphy's vigilantes outside (1979: 191-2)

Of the female-authored novels, The copper crucible invites compassion for a girl who 'goes through' the single men's barracks 'at a fiver a time' (1996: 21), while Kay Brown's story of Big Doll is a long, sentimental filling-out of the 'whore with a heart of gold' stereotype. Contrary to the male-authored novels, Knock ten finds unambiguous generosity and strength in a female sex worker (1976: 180).

The epic scale of the Golconda trilogy allows space for a multi-faceted depiction of female characters. Women's arrival at the mining settlement heartens the men as a civilising sign, but the description also assumes wives' confinement to domestic tasks:

Buoyancy was in the air, a feeling of life opening up ahead. It was quickened by the presence of women, who were gradually trickling into the field and giving colour and variety to the dusty flat, even though they were mainly the wives of working-miners with young children to look after and no time to raise their eyes from washtubs or cooking fires. Yet the sight of print frocks fluttering among the saplings and youngsters carrying parcels home from the store gave the place a settled air. (1972: 103)

A second evocative and equally well written account summarises the gendered fundamentals of the mining field's mindset by stressing female invisibility:

They had come unnoticeably, these women, singly or in couples, emerging warily from the heaped-up packages and mailbags of the service-bus and standing lost and bewildered for a while in the open space by the store till their men claimed them and carried them off to their shanties in the undergrowth. There they slipped off their travelling finery and donned house-clothes that seemed to render them 
invisible. There was nothing to tempt them out from behind their flimsy walls and there they stayed in obscurity, their presence betrayed only by an occasional pram under a tree or white rags fluttering from a stretched piece of wire. (1972: 117)

May Varnek and Dora Venn, both of them large in body and in spirit, nevertheless challenge the invisibility of Golconda's women in a narrative that glosses their prescribed maternal roles with the romance of pioneering.

According to Mahony, May has 'thrown herself away on one waster after another' (1972: 37), and her physical decline is evident to Donovan from their first meeting. He nevertheless imbibes wisdom from her stoical calm and modelling of acceptance. When the opening of the picture theatre brings Golconda people together in celebration, May 'comes out into the daylight' (1972:123) in a dance that creates a 'homely community-feeling' and symbolises her cohesive role as the heart of the town. This role is confirmed when her death releases pre-existing centrifugal forces: the young Neda flees with Farelli and the gougers scatter. Dora shares May's status of a 'woman with a past', one who has been deserted or abused by nonAustralian men. As the teacher, she becomes the protector of Golconda's women and children (1972: 139) — for example, by sharing her home with the motherless Neda. She also saves Mahony from fever, and thereby initiates the trilogy's only happy sexual relationship.

As strong women, May and Dora sustain community among the miscellaneous men who have converged on Golconda. Palmer venerates the maternal principle that he sees as ruling such women, and that he embodies in Neda's early sculptures (1972: 118). However, the healing earth-mother figure is the opposite of Neda herself, who is only intermittently maternal towards her son. Neda in fact epitomises the mystique that Palmer regards as the essence of the female artist. He locates a more purely erotic mystique in the foreignness of Keighley's wife, Carita, who has a fling with Donovan at the dance at Golconda enlivened by May's performance. Later, from the expensive nest on the Bluff in Townsville funded by Keighley's managerial earnings, Carita rejects Donovan's attempt at reconnection.

The women Donovan meets after he leaves Golconda are on the whole less admired than the pioneering Golconda women. In Seedtime (1957a), he chooses to marry Kitty, the eldest of the Hegarty family, who has raised her younger siblings, because he prefers Kitty's realism over her sister Judy's romantic obsession with him. By the beginning of The big fellow (1973), the sexual and emotional aspects of the marriage have failed, and Kitty's self-image as a family woman leads her into a blunder that destabilises Donovan's position as Premier. However, the ending chillingly reaffirms her maintenance of the façade of politician's wife into the future, at a cost in genuine fulfilment that both partners tacitly agree not to explore:

He knew where they would clash, but it did not seem to matter very much. There was a bond between him and this woman that could make light of day-to-day tensions and did not depend upon intimacies. She had not cast his affair with Neda up at him or whined about his political defeat. He could count on her standing behind him, cheerful and high spirited, in whatever fight lay ahead. (1973: 297)

In Golconda, women's heroism therefore consists of caring for men. In The copper crucible (1996), by contrast, it takes the form of fighting for emotional 
survival, the survival of marriages and children's welfare, in intolerable conditions. Julie's heroines are Bronwyn, 'tough, wiry and weather-beaten - but somehow perky and indomitable' (1996: 15), and Mollie, who lives for the day her family will revel in a home on the coast. Female solidarity upholds the women's struggles at Mt Irene. The copper crucible fills in the details of domestic privation that Palmer hides under the veil of women's invisibility on the mining field. Examples are the cramped, hot dwelling houses - or, just as often, tin sheds or garages - along with the makeshift furniture, the battered ice chests, the unreliable primus stoves and the struggling vegetable gardens. In Bronwyn's garden, most of the paw-paw trees and pumpkin flowers turn out to be male - 'Too many men here - they outnumber us six to one. Even the plants follow suit.' (1996: 15-16) By contrast, the Greek wives - in whom cultural conditioning proves unshakeable - submit to expectations by cooking elaborate meals, washing clothes, preparing their men's baths and assisting them to wash when they return from the mine. The suffering of all women at Mt Irene is nevertheless unalleviated, either by the romance of pioneering or by the vision of a just community - the hope that in Golconda dies with Christy Baughan. Instead, Julie's demand for equality in marriage (1996: 170) heralds the feminist reawakening of the late 1960s. Despite its success in communist Russia, The copper crucible is a feminist rather than a proletarian text.

In Knock ten (1976), the narrative perspective and voice of Lee Cleary, and the equal attention paid to male and female characters, depart from the maleauthored novels' acceptance of the mining industry as a masculine domain. While not professing to be a feminist work, Knock ten celebrates transgression as a sign of female maturity. For example, when Mary Rose O'Brien is about to marry Nigel, the son of the mine's general manager, in the wedding of the year, the ringing of 'knock ten' brings the bride in her expensive regalia to the pit head, fearing for her true love, Thad (1976: 266). Lee is shocked at this breaching of the gender boundary between Townside and Mineside,

at her not knowing that miners' women didn't DO that — didn't race to that place of men's work. Not there - not to the poppet head ... I had to show her women waited - waited holding all that screech and tear and agony inside, and quiet. Women stayed in their homes and just waited, and waited, and waited. (1976: 267)

Lee herself finally defies her admirable, pious mother, who to her cost has always maintained such boundaries, in a transgressive leap that is seen as crowning her maturity (1976: 299-300).

By contrast, the female characters in Kangaroo court are victims of Kovac's lust or violence - though sometimes, like Daisy, ambiguously or incompletely so. Murphy's wife Kath rejects Kovac after discovering his attraction to her daughter, and Kovac's wife Ellie quits after years of slavery when Kovac sadistically destroys her garden: her one joy. These desertions provoke his fateful approaches to the schoolgirls, who are merely curious and untroubled by the sex games, until they erupt into violence. In Blood stains the wattle, female characters fall into the madonna-whore binary, as Peter records his sexual performances with the nurse Margaret, in parallel with his growing commitment to Patricia O'Donoghue, virtuous Catholic daughter of the local AWU organiser. Similarly, Jack Long, Lilley's 
stand-in in The channels (2001), refers to women mainly in terms of male sexual frustration or fulfilment.

\section{Conclusions}

The map of the Mt Isa mind - the nexus of ideas and assumptions relating to the mine and city - that emerges from this study of the fiction is complex, yet some conclusions are clear. The first is that the eight novels feature dystopic, female, migrant and proletarian experiences that are suppressed in Blainey's history. Second, the Golconda trilogy and Kangaroo court explore different kinds of male vulnerability, including in the former changes occurring in Australian men's selfimage during the middle decades of the twentieth century. Third, except for Knock ten, which adheres to a dogma of inclusivity, the novels demonstrate an ambivalent attitude to non-English and non-Irish immigrants. Fourth, Aboriginal people are a notable absence from the twentieth-century Mt Isa mind, but rare references portray them as mysterious, threatening or abject. Fifth, while only The copper crucible is an openly feminist text, all the novels acknowledge women's presence on the mining field. Golconda confines complex female portraits within maternal and womanartist paradigms; Knock ten encourages the crossing of gender boundaries; and Jost, De Lacy and Lilley present women primarily as sexual partners for men. Sixth, all the novels are loyal to working-class men and women, if not to leftist ideology. The Mt Isa novels can therefore indeed claim, as Ian Syson argued in 1995, to be a literature of the people.

\section{Endnotes}

1 The ABC 2009 TV series Dirt Game brought this romance up to date. In January 2013, the SBS series Dirty Business: How Mining Made Australia balanced romance by exploring some of the ways in which mining has shaped Australian history and culture.

2 Blainey refers to a large influx of Fins from the canefields in the late 1920s, 'making Mt Isa the largest Finnish community in Australia' (1970: 157).

3 See Sid Domic's limited edition prints, "Battle Mountain" and "Corroboree at Battle Mountain", http://www.siddomicart.com/inc/sdetail/170/179. Sid Domic was born and raised in Rockhampton, and first journeyed to Mt Isa in 2006 in order to explore his Kalkadoon heritage. Before his retirement from professional Rugby League in 2007, he played for the Brisbane Broncos and the Penrith Panthers, as well as for the Warrington Wolves and other English Superleague teams.

4 Janet Fountain worked in Mt Isa on technical computer programs for the mining industry from 1987 to 2002. Her Mt Isa landscape paintings (1998-2002) include 'Under Gidgea', 'The Granites of Mount Guide,' 'Bloodwood (Eucalyptus Terminalis)', 'No Rain Since March', 'Granite Spaces', 'Razorback Ridges', 'Peaks of Micavale', 'Desert Rose among Granites' and the panel 'Twenty Minutes South of Mt Isa'. See http://www.janetfountain.com/index.htm.

5 Golconda (or Golkonda), a ruined fortress city west of Hyderabad in south-central India, was the capital of the medieval kingdom of Golconda (c. 1364-1512) and the market city for the region's diamond industry. Gems traded came mostly from mines in the surrounding districts, but from the Renaissance onwards Europeans associated Golconda itself with the mining of fabulous diamonds. Golconda provenance is attributed to the Hope Diamond, the Koh-i-Noor, the Regent Diamond, the Wittelsbach Diamond and other legendary stones. By the 1880s, English speakers were using Golconda generically to refer to any particularly rich mine. 
6 Cosme was Lane's breakaway colony in Paraguay, founded after rifts developed within the first colony of New Australia.

\section{References}

Blainey, Geoffrey 1970 [1960]. Mines in the spinifex: the story of Mount Isa Mines, rev ed. Sydney: Angus \& Robertson.

Brown, Kay 1976. Knock ten. Sydney: Wentworth Books.

Casey, Gavin 1992. 'Short-shift Saturday', in L. Hergenhan (ed.), The Australian short story: A collection 1890s-1990s. St Lucia: University of Queensland Press, pp. 7099.

Collins, Betty 1996 [1966]. The copper crucible: a novel, new ed., intro. Ian Syson. St Lucia: University of Queensland Press.

Croft, Julian 1988. 'Responses to modernism, 1915-1965'. In L. Hergenhan (ed.), The Penguin new literary history of Australia. Ringwood: Penguin, pp. 409-29.

De Lacy, Keith 2002. Blood stains the wattle. Rockhampton: Central Queensland University Press.

Jost, John 1979. Kangaroo court. London: Angus \& Robertson.

Lilley, Merv. 2001. The channels. Melbourne: Vulgar Press.

Palmer, Vance 1972 [1948]. Golconda. St Lucia: University of Queensland Press.

Palmer, Vance 1957a. Seedtime. Sydney: Angus \& Robertson.

Palmer, Vance 1957b. 'Return to Mt Isa: among the metal-minded men of Queensland'. The Age Literary Supplement, 19 October: 1.

Palmer, Vance 1973 [1959]. The big fellow. St Lucia: University of Queensland Press.

Syson, Ian 1995. 'A copper tale: literature in the Isa', Coppertales: A Journal of Rural Arts 2, 57-65. 